\title{
Pogranične zajednice u Republici Hrvatskoj: istraživanje lokalnoga identiteta u pograničnom području Gorskoga kotara
}

\section{Marta Zorko}

Fakultet političkih znanosti, Sveučilište u Zagrebu, Hrvatska e-mail:mzorko@fpzg.hr

\section{Ivan Šulc}

Prirodoslovno-matematički fakultet, Geografski odsjek, Sveučilište u Zagrebu, Hrvatska

e-mail: isulc@geog.pmf.hr

\section{Marko Kovačić}

Fakultet političkih znanosti, Sveučilište u Zagrebu, Hrvatska e-mail:mkovacic@fpzg.hr

\begin{abstract}
SAŽETAK S obzirom da je došlo do promjene zbiljnosti pojma granice u suvremenom svijetu, sve se više pažnje u istraživanjima pridaje mikroregionalnim društvenim entitetima u pograničnim područjima i njihovim međusobnim odnosima, kako prema centrima, tako i prema onima u okruženju. S obzirom da je promjena koncepta geopolitičkoga pojma granice u postmodernom svijetu nastupila u okviru trokuta odnosa prostor - moć - stanovništvo, jedino interdisciplinarnim istraživanjem moguće je istražiti navedeni fenomen u ukupnom njegovom značenju. Rad analizira društvene identitete i istražuje koheziju u krajnjem sjeverozapadnom dijelu Gorskoga kotara - u hrvatsko-slovenskom pograničnom području. Kombinacijom kvalitativnih i kvantitativnih istraživačkih metoda u radu je argumentirano da istraživano geografsko područje posjeduje društvenu koheziju i razinu identiteta koja ga čini pograničnom zajednicom. Srž i pozadina te kohezije detaljno je prikazana u ovom radu.
\end{abstract}

Ključne riječi: identitet, društvena kohezija, Gorski kotar, pogranične zajednice, prekogranična suradnja, Republika Hrvatska. 


\section{Uvod}

Evolucijom teorije države, teritorija i granice iz modernoga poimanja u postmoderno, u smislu erozije suvereniteta, deteritorijalizacije i globalizacije, pojavljuje se pojam pograničnih područja (borderlands). Navedeni pojam odnosi se na pogranične regije unutar više država i njihovu međusobnu suradnju. Često je na taj način u literaturi posebno naglašen prostorni koncept granice. Taj širi prostorni koncept odnosi se na pojas s jedne i druge strane granice, koji ima određene zajedničke karakteristike. Ovakva pogranična zona suradnje za neke autore predstavlja novi oblik (suvremenoga) frontiera (Martinez i Gallusser, 1995.; Gamster i sur., 1997.; Rumley i Minghi, 1991.; prema: Newman i Kliot, 2000.:12). Iako se teze o deteritorijalizaciji i nestajanju značaja granica pod utjecajem silnica postmodernoga doba mogu osporiti, neminovno je da su granice izmijenile svoju funkciju i da se moraju proučavati izvan isključivoga konteksta prostora, što je do sada bio slučaj. Ó Tuathail tvrdi da zapravo nije na snazi deteritorijalizacija, već reteritorijalizacija. Teze ovoga autora usmjerene su prema saznanju o rekonfiguraciji značaja granice na nekoliko razina (Ó Tuathail, 1998.). Iako se možda čini da državne granice gube svoj značaj, granice na nižim, lokalnim razinama, kao i one globalne, itekako ostaju važne i postaju sve vidljivije. Takva rekonfiguracija značenja granice otvara prostor za novo poimanje i definiranje pograničnih područja. Bilo da se radi o jednoj zajednici s obje strane granice - prekograničnoj regiji, ili pak o dvije zajednice koje dijeli granica, srž za definiciju takvoga područja čini stanovništvo koje naseljava pogranični prostor, i tvori svojevrsnu zajednicu za sebe. Međusobna suradnja unutar takve zajednice jača je nego ona matičnih država na državnoj razini (Cvrtila, Zorko i Banovac, 2010.). Razina kohezivnosti, postojanje zasebnoga identiteta i suradnja na lokalnim razinama određuju radi li se o pograničnim područjima ili pograničnim zajednicama. Upravo istraživanje postojanja takvoga identiteta, te njegova analiza na konkretnom primjeru, središnji je cilj ovoga rada.

Klemenčić je potkraj dvadesetoga stoljeća izradio studiju o utjecaju otvorenih graničnih pitanja na međusobne odnose Hrvatske i Slovenije. Zaključio je da, iako otvorena granična pitanja itekako narušavaju odnose na državnoj razini i percepciju među građanima na ukupnom planu, odnosi na lokalnoj razini imaju svoju dinamiku. Ljudi u pograničnim područjima, iako bi se njih najviše trebali ticati problemi oko protezanja granične linije, "međusobno surađuju" (Klemenčić, 2001.:21). Kohezija stanovništva koje živi u pograničnim područjima, ali i njihovi motivi i želje, "vrlo se često razlikuju od onih na državnim razinama" (Cvrtila i sur., 2010.:18). Dobra suradnja u pograničnom području Gorskoga kotara, bez obzira na razmirice Hrvatske i Slovenije oko granice, često se spominje kao pozitivan primjer u hrvatskim medijima. Stoga, pretpostavljamo kako u pograničnom području sjeverozapadnoga dijela Gorskoga kotara postoji društvena kohezija koja omogućava definiranje toga prostora pograničnom zajednicom. U ovom radu istražit će se razina spomenute kohezije, postojanje zasebnoga identiteta i analizirati odnosi ove pogranične zajednice prema centru i prema susjednom prekograničnom području u Republici Sloveniji. Uz to, ispitat će se postoje li prostorne razlike u jačini lokalnoga identiteta, ovisno o geografskom položaju, u odnosu na granicu i stupnju prometne izoliranosti od (sub) regionalnih središta te analizirati potencijalne razlike. 
Područje istraživanja čini krajnji sjeverozapadni dio Gorskoga kotara u hrvatskoslovenskom pograničnom području (slika 1.). Promatrani prostor obuhvaća tri jedinice lokalne samouprave: Grad Delnice, Grad Čabar i Općinu Brod Moravice ${ }^{1}$. Na području navedenih općina nalazi se 134 naselja, i to 38 u Općini Brod Moravice, 41 u Gradu Čabru i 55 u Gradu Delnice (DZS, 2011.b). S obzirom na prirodno-geografska obilježja i povijesno-geografski razvoj, sva veća naselja i važnije prometnice smješteni su u sjeveroistočnom (dolina Kupe i Čabranke -naselja Čabar, Prezid, Brod na Kupi) i jugoistočnom dijelu promatranoga prostora (središnji ili delnički koridor - naselje Delnice), a zapadni je dio gotovo nenaseljen (risnjačko-snježnički gorski blok) (Njegač i Pejnović, 2002.). Sve tri općine graniče sa Slovenijom, i to sa slovenskom povijesno -geografskom regijom Kranjskom, odnosno Notranjskom na krajnjem sjeverozapadu i Dolenjskom na sjeveru i sjeveroistoku. Važniji obližnji slovenski gradovi su Stari Trg i Cerknica, Postojna, naselja Prezid, te Ribnica, Černomelj i Metlika. Hrvatsko-slovenska granica prolazi obroncima planine Snježnik te dolinama Čabranke i Kupe. Na području promatranih općina nalazi se pet graničnih prijelaza - međunarodni granični prijelazi Prezid i Brod na Kupi, granični prijelaz za pogranični cestovni promet Čabar i Zamost, te sezonski granični prijelaz Prezid (Carinska uprava RH (CURH), 2011.).

Slika 1.

Položaj općina Čabar, Delnice i Brod Moravice

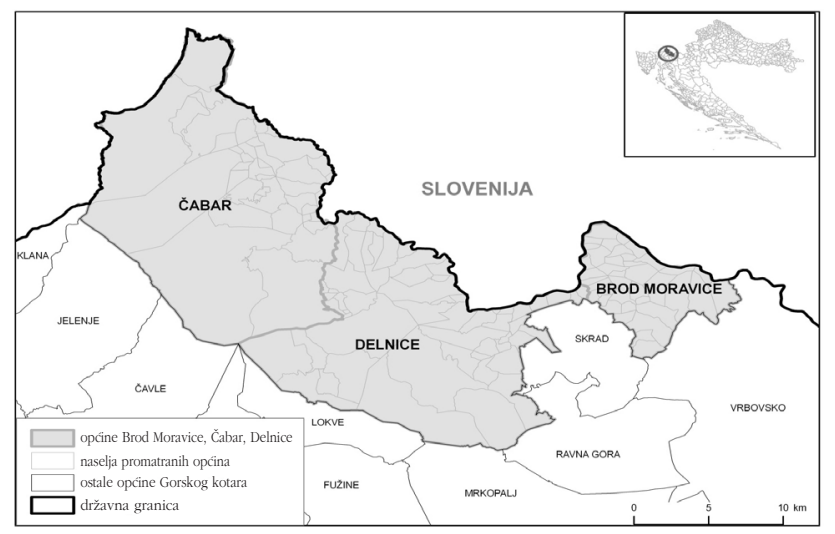

1 U administrativno-teritorijalnom ustroju Republike Hrvatske gradovi i općine su jedinice lokalne samouprave. Općine se osnivaju za "više naseljenih mjesta koja predstavljaju prirodnu, gospodarsku i društvenu cjelinu, te koja su povezana zajedničkim interesima stanovništva" (Zakon o lokalnoj i područnoj (regionalnoj) samoupravi (ZLPS), NN 33/01). Administrativni pojam grad (Grad s velikim početnim slovom) čini sjedište županije, naselje s više od 10.000 stanovnika i okolna naselja koja s njim čine gospodarsku i društvenu cjelinu te mu gravitiraju, ili, iznimno, naselja koja ne zadovoljavaju ove kriterije, a imaju status grada zbog posebnih razloga (povijesnih, prometnih, gospodarskih) (ZLPSS, NN 33/01). Budući da administrativni grad predstavlja općinu sa središtem u gradskom naselju, radi izbjegavanja konfuzije za sve tri jedinice lokalne samouprave u množini koristit će se pojam općine (jer prema kriterijima izdvajanja općina one to zaista i jesu), dok će se pojam grada koristiti u svom temeljnom značenju za subregionalni centar Delnice i područni centar Čabar (više o modelu diferencijacije urbanih, ruralnih i prijelaznih naselja u Hrvatskoj vidjeti prema: Državni zavod za statistiku (DZS), 2011.a). 


\section{Metodološki okvir}

S ciljem dobivanja dubinskoga uvida u način funkcioniranja lokalne zajednice u radu se koriste sljedeće istraživačke metode - studija slučaja, anketno istraživanje i terensko opažanje. Studija slučaja je u ovom istraživanju prikladna iz nekoliko razloga. Prvo, odgovara na pitanja kako i zašto. Fenomen koji ovaj rad istražuje, pogranične zajednice, može se prije svega okarakterizirati kao suvremen, što je i drugi razlog prikladnosti korištenja navedene metode. Treći razlog za korištenje ove metode sadržan je u neutralnosti istraživača, koji koristeći studiju slučaja ima malu ili nikakvu kontrolu nad fenomenom koji proučava. Kako se u metodološkoj literaturi navodi, "studija slučaja najpogodnija je metoda u slučaju da je pitanje kako i/ili zašto postavljeno o skupu suvremenih događaja nad kojima istraživač ima malu ili nikakvu kontrolu" (Yin, 2007.:18). John Gerring pronalazi četiri razloga zbog čega metoda studije slučaja postaje sve atraktivnijom za provođenje politoloških istraživanja. Smatra da se "više ne podrazumijeva kako neeksperimentalni podaci dobiveni analizom nacionalnih država, gradova, društvenih sukoba ili ostalih složenih fenomena moraju biti obrađivani standardnim načinima. [...] razvijen je niz alternativa standardnom linearnom modelu unakrsne analize više slučajeva (cross-case study), [...] umreženi su alati metode racionalnoga izbora i studije slučaja pod nazivom analitičke priče (analytic narrative), [...] epistemološki zaokreti priznali su atraktivnost ove metode" (Gerring, 2007.:3 - 5).

Metode koje spomenuti autori predlažu za provođenje studija slučaja primarno su kvalitativne metode analize, od kojih ćemo se i mi služiti nekima: povijesnom, etnografskom, tekstualnom i metodom ankete, kao kvantitativnim alatom. Jedine metode za prikupljanje podataka koje su svojstvene isključivo studiji slučaja su eksperiment, etnografsko istraživanje na terenu, nestrukturirani intervju i strukturirana anketa (Gerring, 2007.). Dakle, uz analizu i sintezu postojeće primarne i sekundarne literature i dosadašnjih istraživanja, dokumenata i arhivskih zapisa (karte, popisi stanovništva), jedna od metoda prikupljanja podataka, koja se koristi u ovom radu, jest strukturirana anketa.

Anketno istraživanje na uzorku od 147 stanovnika sjeverozapadnoga dijela Gorskoga kotara (1,4\% populacije promatranoga područja) provedeno je 27. kolovoza 2011. u naseljima Čabar, Gerovo, Kozji Vrh, Prezid i Tršće u Gradu Čabru, u naseljima Brod na Kupi i Delnice u Gradu Delnicama, te u naseljima Brod Moravice i Čučak u Općini Brod Moravice. Anketiranje je provedeno prema sistemskom uzorku na temelju prostornoga razmještaja broja stanovnika po općinama i naseljima. Dakle, cilj je bio u svakoj od triju promatranih općina anketirati broj osoba koji odgovara udjelu od 1,5\% ukupnoga stanovništva te općine te isti princip primijeniti i na broj ispitanika po naseljima unutar svake općine (uvjet za svrstavanje ispitanika po naseljima bio je mjesto uobičajenoga stanovanja, dakle u obzir su uzete samo osobe koje stanuju u općinama promatranoga prostora). U Gradu Čabru je anketirana 61 osoba ili 42,5\% ukupnoga broja ispitanika (Grad Čabar participira u stanovništvu promatranih općina s 35,5\%), od čega 21 osoba u Prezidu, 17 u Gerovu, 11 u Čabru, 11 u Tršću i 
1 u Kozjem Vrhu. U Gradu Delnicama anketirano je 72 ispitanika ili 49,0\% ispitanika (Grad Delnice participira u stanovništvu promatranih općina s 56,4\%), od čega 65 u Delnicama, a 7 u Brodu na Kupi. U Općini Brod Moravice anketirano je 14 ispitanika ili 9,5\% ukupnoga broja ispitanika (udio Općine Brod Moravice u populaciji promatranoga područja iznosi 8,1\%), od čega u Brodu Moravicama 13, a u naselju Čuček 1 ispitanik. Odstupanja broja i udjela ispitanika po općinama od željenoga iznosa rezultat je otežanih uvjeta anketiranja, odnosno teškoga pronalaska ispitanika koji su pristali na sudjelovanje u istraživanju i visokoga stupnja odbijanja potencijalnih ispitanika da sudjeluju u anketi.

Kako je jedan od ciljeva rada identificirati i opisati lokalni identitet, te istražiti njegov utjecaj na način življenja u ovom pograničnom području, anketno istraživanje formulirano je pitanjima o percepciji vlastitoga života (samorefleksija) ${ }^{2}$. Operacionalizacijom i obradom podataka dobivena je struktura i priroda kolektivnoga identiteta koji utječe na prirodna i socijalna kretanja stanovništva. U analizi društvenogeografskih obilježja promatranoga prostora korišteni su dostupni podaci (prvi rezultati) popisa stanovništva 2011. godine ${ }^{3}$. Na temelju podataka o broju stanovnika po naseljima i podataka vitalne statistike (do 2009. godine) izračunato je i iskazano kretanje stanovništva ${ }^{4}$. S obzirom na nedostupnost podataka o sastavu stanovništva za posljednji popis, u radu se koriste podaci o sastavu stanovništva za 2001. godinu koji su provjereni i nadopunjeni terenskim istraživanjem.

\section{Teorijski okvir i dosadašnja istraživanja}

Proučavanjem fenomena granice iz geopolitičke perspektive može se prepoznati njezin trojaki karakter - geografski, politički i socio-kulturni. I dok su geografski i politički složeni, ali odredivi, socio-kulturni karakter je teško znanstveno utemeljeno odrediti jer sadrži mnoge komponente, uključujući kulturu i društvo, koji nemaju jednoznačne granice. S tim se slaže i Bufon koji, iako uvodi novu kategoriju,

2 Joanna Kurczewska samorefleksiju navodi kao ključni segment istraživanja pograničnih područja (Kurczewska, 2006.).

3 Podaci su prikupljeni su po metodi place of usual residence, odnosno u ukupno stanovništvo naselja popisa ulaze sve osobe koje su uoči kritičkoga trenutka popisa (31. ožujka 2011.) živjele neprekidno u svome uobičajenom mjestu stanovanja barem 12 mjeseci (DZS, 2011.b).

4 Podaci vitalne statistike za 2010. godinu predstavljaju prosječnu godišnju stopu rodnosti i smrtnosti za razdoblje 2001. - 2009. 
antropogeografske granice, u klasifikaciju granica5, navodi da je o kulturnim područjima nemoguće govoriti u okvirima linija ili granica. Tu se radi o područjima (zonama, po Bufonu) ispreplitanja i međusobnih utjecaja. Budući da je teško iscrtati političku granicu na temelju kulture, koja predstavlja više zonu prožimanja nego linearnu crtu razdjelnicu, proces razgraničenja po principu kulturnih granica u praksi se često oslanja na razne druge "uporabnije" granične linije fizičkoga ili društvenoga tipa koje se nalaze u blizini (Bufon, 2001.). I dok geopolitika naoko zaobilazi analizu razgraničenja prema kulturnim i društvenim osnovama, socijalna geografija i sociologija daju okvire i pozadinu za istraživanja ovakvoga tipa. Također, moguće je zamijetiti i kako su ovakva istraživanja sve više zastupljena u radovima suvremenih autora kritičke geopolitičke prominencije, koji uviđaju da je došlo do promjene zbiljnosti fenomena granice.

Newman i Paasi zaključuju kako geografi diskursa kritičke geopolitike, inspirirani nedavnim raspravama škola i teorijama međunarodnih odnosa, sve više propituju geografske pretpostavke i empirijske koncepte granice. Oni predlažu da se pažnja usmjeri prema praksama stvaranja granice i pitanjima identiteta, te tvrde kako su sve granice društveno konstruirane. Sve navedeno znači da pitanje moći postaje ključno pitanje ukoliko govorimo o granicama (Campbell, 1992.; Dodds, 1994.; Massey i Jess, 1995.; Ó Tuathail, 1996.; Agnew, 1993., 1997.; prema: Newman i Paasi, 1998.:188). Stoga isti autori predlažu suvremeno izučavanje granice u multidimenzionalnom kontekstu i zamjećuju četiri suvremene rasprave unutar studija o granicama koje su povezane zajedničkim poljem istraživanja - poveznicom između teritorijalnosti, linije ograničenja i identiteta. Navedene rasprave su: rasprava o nestajanju granica, rasprava o konstrukciji društveno-prostornih identiteta, teritorijalne priče (granice isključivanja i uključivanja), te granice i njihove prostorne razine (Newman i Paasi, 1998.).

Nadalje, Mladen Klemenčić smatra kako se do sada fenomenu i istraživanju granica u znanosti pristupalo isključivo na tradicionalan način. Tradicionalni pristup temi političkih granica na kopnu uključivao je dva osnovna smjera istraživanja. Prvo, smještaj, narav i nastanak granice, uključujući i ocjenu njezine "povoljnosti" sa stajališta jedne od graničnih država. I drugo, utjecaj granice na okolni krajolik, stanovništvo koje živi u tom području i oblikovanje vanjske politike koju država vodi

5 Geopolitički gledano, postoje razne podjele granica, ali se sve mogu razvrstati u tri grupe - morfološku podjelu (čiji su dio podjela na prirodne i ugovorne granice), genetsku podjelu i funkcionalnu podjelu. Genetska podjela potječe od Hartshornea, a odnosi se na njihov nastanak, pa se tako razlikuje pionirske, antecedentne, subsekventne, nametnute i reliktne granice (Hartshorne, 1936.:56 - 57). Funkcionalna podjela podrazumijeva podjelu granice prema njezinoj funkciji, opet u odnosu na društveni element s njezine obje strane. Tako možemo razlikovati barijerne granice, koje odjeljuju, filtrirajuće granice, koje su polupropusne, kontaktne granice, koje spajaju i integratione granice kao pojavu unutar Europske Unije, gdje granice nacionalnih država i dalje postoje, ali su u potpunosti otvorene za članice te zajednice. Naposljetku, morfološka podjela granica koja, poput geografske klasifikacije, granice dijeli na prirodne i geometrijske, nadopunjena je od strane Bufona antropogeografskim granicama koje prate linije društva. 
(Klemenčić, 2005.). Problematiku svih tradicionalnih limitoloških radova u političkoj geografiji Klemenčić vidi u njihovu prihvaćanju nacionalne države kao neupitne pojave, čime su granice bile nedodirljive i prirodno zadane. Suvremeni kritički pristup prema njemu se zasniva na uviđanju novih funkcija granica (njihova propusnost) i novim razinama promatranja (lokalne razine). Još jedan od potpuno novih pristupa koje navodi Klemenčić jest Paasijeva veza granica i nacionalnoga identiteta. Paasi polazi od tvrdnje da su granice ponajprije socijalni proizvodi. On granicu promatra kao dio diskurzivnoga krajolika koji se svakodnevno posreduje i reproducira na više načina, primjerice putem medija, prevladavajuće političke retorike ili kroz obrazovni sustav (Klemenčić, 2005.).

Rumley i Minghi stvorili su okvir za suvremeno izučavanje granice i predlažu četiri razine istraživanja toga fenomena: (1) istraživanje društvene diferencijacije između i unutar država u smislu kulture i svijesti; (2) ekonomska diferencijacija u smislu ekonomskih aktivnosti; (3) politička diferencijacija u smislu sustava vlasti, administracije, sigurnosti i izbora i (4) interakcija između država vezana uz pitanje granica, koje se odnosi na političke ishode međudržavnih odnosa, i mogu gradirati od rata do suradnje (Rumley i Minghi, 1991.). U okviru ovih prijedloga može se pristupiti proučavanju stanovništva u pograničnim područjima, te analizirati (1) kakva je svijest o pripadnosti i kohezivnost prisutna u takvim zajednicama prema stanovništvu s druge strane granice, a kakva prema "centru" (pod pretpostavkom da je pogranično područje periferija); (2) kakva je ekonomska aktivnost i međuovisnost pograničnih zajednica; (3) postoje li i kakvi su propisi koji se odnose na stanovništvo u tom području (jesu li dobrovoljni ili imperativni) i (4) kako "centri" gledaju na odnose općenito, odnosno potiču li svojim mjerama, instrumentima i akcijama kohezivnost u pograničnim područjima s obje strane granice ili je onemogućavaju. U ovom radu istražit će se upravo prva spomenuta razina, odnosno svijest o pripadnosti i identitet istraživanjem definiranoga pograničnog područja u Republici Hrvatskoj.

Ideja zajednice u društvenim znanostima, a posebice u sociologiji, doživljava svojevrsnu renesansu. Pozornost se pridaje tzv. studije zajednice (community studies) koje obuhvaćaju ruralne zajednice, male gradove i zajednice lokalne klase, te imaju holističku tendenciju (Geiger Zeman i Zeman, 2010.:42), odnosno proučavaju sveukupnost motiva i gradivnih elemenata pojedinih zajednica. Day definira zajednicu kao "one stvari koje su ljudima zajedničke [...] i koje im daju osjećaj međusobnog pripadanja” (Day, 2006.:1). Tvrdeći da zajednice uključuju ljude u jednu socijalnu sferu, ali istovremeno i isključuju druge iz nje, neraskidivo veže zajednicu za koncept identiteta. U razmatranju tematike nemoguće je zaobići Tönniesovu distinkciju između pojmova Gemeinschaft i Gesellschaft. Tönnies smatra da je društvo apstraktniji oblik u kojem prevladava mehaničnost, atomizacija i impersonalnost (Gesellschaft), dok je zajednica (Gemeinschaft) intimnija, personalnija, manja organska verzija društva. Slijed ljudskoga razvoja pokazuje tendenciju zamjene odnosa zajednice društvom ${ }^{6}$ (Tönnies, 2002.). Naznačena teza i jest jedan od razloga interesa

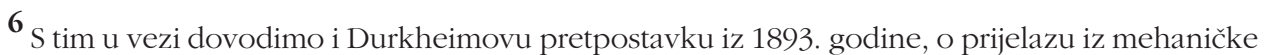
u organsku solidarnost, čime je otvorio put tradiciji proučavanja koncepta zajednice. 
društvenih znanstvenika za koncept zajednice, tj. može li ona opstati, mijenja li se i koja je njezina uloga u složenijem društvenom sustavu?

S obzirom na tematiku ovoga rada, od posebne je važnosti zajednica mjesta. Zajednicu mjesta čine "skupine ljudi koji žive jedni do drugih na određenom prostoru i dijele određene vrijednosti, iskustva i interese" (Geiger Zeman i Zeman, 2010.:74). Dakle, zajednice mjesta obuhvaćaju sve čimbenike koji determiniraju osjećaj privrženosti ljudi s nekim prostorom. U to se uključuje kolektivna memorija, tradicija i osjećaj različitosti u odnosu na neki drugi društveni entitet. Granice zajednice bitan su faktor i definicije same zajednice. One su simbolično razgraničenje nas i njih, te kao takve obuhvaćaju identitet zajednice kojoj pripadamo.

Pojam identiteta u suvremenim je društvenim znanostima postao nezaobilazna tema. Identitet je u osnovi kontekstualni pojam koji, najjednostavnije, označava osjećaj tko sam ja, tj. tko smo mi. Bhiku Parekh kaže da se "identitet neke stvari sastoji u svojstvima koja je tvore tako da određuju kao tu stvar ili tu vrstu stvari, a ne kao drugu, te je razlikuju od svega ostaloga” (Parekh, 2008.:13). Načelno se razlikuju dvije osnovne vrste identiteta: individualni ili osobni i kolektivni ili grupni. Individualni identitet se odnosi na "vjerovanje i vrijednosti pomoću kojih se (pojedinci) određuju ili identificiraju kao određena vrsta osobe" (Parekh, 2008.:15). Ovo je način na koji se artikulira i konstruira samoga sebe i svijeta koji okružuje tu osobu. Osobni je identitet, čini se, dvostruk. S jedne strane, određuje ga okolina, u smislu socijalizacije, obitelji i društva u kojem se nalazimo, dok s druge strane predstavlja izbor, što je i važniji segment osobnoga identiteta. Naime, okolina nam može dati određene koncepte i ponuditi različite varijante vrijednosti, no mi smo ti koji kritičkim mišljenjem odbacujemo ili pak prihvaćamo te vrijednosti. Djelovanjem konstruiramo vlastiti identitet.

Grupni identitet "počiva u skupini elemenata koje prepoznajemo kao zajedničke svima nama i dostatne kako bismo se držali zajedno, da bismo osjetili ono "mi'" (Cerutti, 2006.:24). Sam po sebi, grupni se identitet može smatrati izvedenicom osobnoga identiteta. Mi ipak moramo u svijesti imati predodžbu da pripadamo konkretnoj zajednici i ponašati se u skladu njezinih tradicija. Društvene uloge koje pojedinac obnaša u skladu s normama nekoga društva, ogledalo su identiteta jer baš iz razloga pripadanja poštujemo neka pravila nametnuta od strane zajednice. Ono što valja istaknuti je element pripadanja. Identitet je jedan od komponenata pripadanja, odnosno definiranja (ne)članom neke socijetalne zajednice. On nas odvaja od drugoga i uspoređuje toga drugog s nama. Pojam drugoga od važnosti je za politike identiteta jer, ne samo što odvaja nas i njih, već u tom odvajanju gradi nas, konsolidira nas i čini svjesnijim onoga što jesmo.

Dvije su još dimenzije identiteta važne za kontekst ovoga članka - nacionalna i lokalna dimenzija identiteta. Nacionalni identitet je podvrsta kolektivnoga identiteta i nastao je kao rezultat borbe nacionalnih država za priznanjem i ostvarivanjem u međunarodnom poretku. Identifikacija naroda s državom bitna je pokretačka snaga povijesti koja je utjecala, ne samo na geografiju, već i na tijek političkih odnosa Europe. Nakon kraja Hladnoga rata i pojave novih država-nacija, fokus je ponovo 
zadobio nacionalni identitet kako bi se objasnili politički procesi novih država i ocijenili pokušaji novih odcjepljenja. Nacionalni identitet gradi se u odnosu na drugoga, a nacionalizam pretpostavlja da svaka nacija treba imati vlastitu državu u kojoj se može neometano i voljno razvijati na način na koji to želi. Nacionalni identitet koji pretpostavlja (ali i konstruira) nacionalnu svijest, snažan je mehanizam političke djelatnosti jer služi legitimaciji odluka vodstva neke države.

S druge strane, lokalni identitet je manifestacija lokalne kulture i karakterizira ga privrženosti zajednici u kojoj se pojedinac nalazi. Lokalni je identitet zanimljiv znanstvenicima jer je povezan s koherentnošću toga dijela društva. Upravo lokalni identitet vrlo snažno utječe na povezanost i homogenost pojedine lokalne zajednice. Lokalni identitet, ukoliko je članovima zajednice važniji od nacionalnoga, često može proizvesti društvene strukture koje su različite od dominantnih u tom društvu, što pak može imati za posljedicu različite gospodarske, gravitacijske pa i političke orijentacije te zajednice. Upravo zato su pogranične zajednice specifične. Tijekom povijesti gradile su posebne društvene odnose s državom s kojom graniče i stvarale tradiciju koja se danas često ne podudara s nacionalnom percepcijom o toj državi. Upravo zato je ideja ovoga rada identificirati najvažnije odrednice lokalnoga identiteta, dovesti u vezu s društvenom kohezijom i povezati ga sa socio-političkim odnosima konkretne zajednice i susjedne države.

\section{Identitet i društvena kohezija u pograničnom području Gorskoga kotara - analiza terenskoga istraživanja}

\subsection{Povijesni i društveno-geografski čimbenici formiranja identiteta}

Za razumijevanje identiteta pogranične zajednice u sjeverozapadnom dijelu Gorskoga kotara nužno je poznavanje povijesno-geografskoga razvoja i suvremenih društveno-gospodarskih mijena. U prošlosti je Gorski kotar, zbog gorsko-planinskoga karaktera i smještaja između jačih životnih žarišta Notranjskoga, Primorja, Like i Peripanonije, dugo imao izolacijski karakter i bio vrlo slabo naseljen. U 15. stoljeću Gorski kotar dobiva važno geostrateško značenje u sustavu obrane protiv Osmanskoga Carstva. Osnivaju se utvrđeni gradovi na strateški istaknutim lokacijama, pri čemu se ističu Brod Moravice i Kostel. Nakon osmanskoga osvajanja Like i Korduna, u 16. stoljeću se malobrojno stanovništvo Gorskoga kotara povlači prema Kranjskoj. Krajem 16. stoljeća, nakon kraćega nesigurnog razdoblja, ponovno se naseljava ovaj prostor, te se u 17. i 18. stoljeću na temelju rudnoga bogatstva razvijaju rudarstvo i fužinarstvo (posebno u čabarskom kraju). Nove gospodarske djelatnosti snažno privlače kajkavsko stanovništvo iz Kranjske i čakavsko iz Primorja. Dakle, u cijelom srednjem i većem dijelu novoga vijeka prisutna je društveno-gospodarska povezanost Gorskoga kotara sa susjednim slovenskim zemljama. U 18. stoljeću Gorski kotar doživljava snažan demografski rast i društveno-gospodarski razvoj zahvaljujući geografskom položaju na kombiniranom podunavsko--sjevernojadranskom transportnom putu koji povezuje Panonsku nizinu i sjeverni Jadrana. Nove gospodarske djelatnosti (trgovina, kirijašenje, ugostiteljstvo) snažno privlače stanovništvo iz okol- 
nih područja Hrvatske, Slovenije i Bosne. Izgradnja Lujzinske ceste (1803. - 1811. godine) daje impuls društveno-gospodarskom razvoju Delnica i okolnoga prostora, a izgradnja željezničke pruge Karlovac - Rijeka (1873. godine) reafirmirala je Delnice kao demografsko i gospodarsko težište Gorskoga kotara (Njegač i Pejnović, 2002.).

Na području općina Brod Moravice, Čabar i Delnice živi 10.597 stanovnika, 48\% stanovništva Gorskog kotara ili 18,5 st./km2 (2011. godine) (DZS, 2011.b). Od ukupnoga broja stanovnika promatranoga prostora dvije petine živi u Delnicama, najvećem gradskom naselju Gorskoga kotara i jedinom naselju s više od 1.000 stanovnika (4.351 stanovnika). Osim Delnica, još devet naselja ima više od 200 stanovnika i u njima živi trećina ukupnoga broja stanovnika promatranoga prostora. Zbog analiziranih prirodno-geografskih obilježja i povijesno-geografskoga razvoja sva veća naselja nalaze se uz doline Čabranke i Kupe (u blizini hrvatsko-slovenske granice) i u središnjem (delničkom) koridoru. Ostalih 124 naselja ima manje od 200 stanovnika, od čega u čak 22 nije zabilježen ni jedan stanovnik (izračunato prema: DZS, 2011.b). Niska gustoća naseljenosti i prevlast vrlo malih naselja posljedica je stočarske valorizacije prostora u prošlosti, a osobito dugotrajne depopulacije, kojom su posebno zahvaćena brdsko-planinska područja i otoci (slika 2.) (Nejašmić, 1992., 2008.). Naime, od 1910. g., kada je zabilježen populacijski maksimum promatranih općina (17.941 stanovnika), do 2011. g. broj stanovnika smanjen je za 41\% (izračunato prema: DZS, 2005., 2011.b). Najintenzivnija depopulacija zabilježena je nakon 1961. godine (indeks promjene broja stanovnika 1961. - 2011. iznosi 65), kada je Gorski kotar, kao i cjelokupni ruralni prostor Hrvatske, zahvaćen snažnom migracijom selo - grad, kao posljedicom snažnoga razvoja industrije u hrvatskim gradovima te niskim životnim standardom na selu (izračunato prema: DZS, 2005., 2011.b) ${ }^{7}$. Delnice, kao lokalno industrijsko središte, apsorbirale su dio te migracije (uglavnom iz okolice) pa nakon Drugoga svjetskog rata bilježe umjereni populacijski rast (1961. godine 4.042 stanovnika, 1991. godine 4.696; indeks promjene 1961. 1991. godine iznosi 116), no i one su nakon 1991. godine zahvaćene depopulacijom (1991. godine 8.527 stanovnika, 2011. godine 6.246; indeks promjene 1991. - 2011. godine 73) (izračunato prema: DZS, 2005., 2011.b).

Sastav stanovništva prema spolu i dobi posljedica je dugotrajne depopulacije. Blagi višak broja žena u odnosu na broj muškaraca (104 žene na 100 muškaraca 2001. godine) odraz je diferencijalnoga mortaliteta ${ }^{8}$ (DZS, 2003.). Istovremeno u proširenoj udajno-ženidbenoj dobi (20 - 39 godina) prisutan je višak muškaraca jer su žene

\footnotetext{
${ }^{7}$ Dugotrajno i intenzivno iseljavanje odrazilo se na smanjenje rodnosti i starenje stanovništva, što ima za posljedicu porast smrtnosti. Zato je u razdoblju 2001. - 2011. godine negativna prirodna promjena (razlika između broja rođenih i umrlih) u ukupnom smanjenju broja stanovnika sudjelovala sa 74\%, a negativna migracijska bilanca (razlika između broja useljenih i iseljenih osoba) 26\% (ukupna međuopisna promjena iznosila je -1.037 stanovnika, negativna prirodna promjena -763, a negativna migracijska bilanca -274) (izračunato prema: DZS 2005.; 2010.; 2011.b).

8 Pojave da je u svim dobnim skupinama smrtnost muškaraca veća od smrtnosti žena pa u starijim dobnim skupinama brojčano prevladavaju žene.
} 
sklonije iseljavanju9. Stanovništvo promatranih općina duboko je zahvaćeno procesom starenja stanovništva. Udio staroga stanovništva (60+) u ukupnom iznosi 25,1\% i dvostruko je viši od vrijednosti iznad koje započinje starenje (12,0\%), te od udjela mladoga stanovništva (21,2\%) (izračunato prema: DZS, 2003.). Navedeno je rezultat iseljavanja mlađega zrelog stanovništva koje sa sobom "odnosi" i svoje buduće potomstvo, što ima za posljedicu smanjenje stope rodnosti i starenje stanovništva.

Slika 2.

Naselja u promatranom području prema broju stanovnika

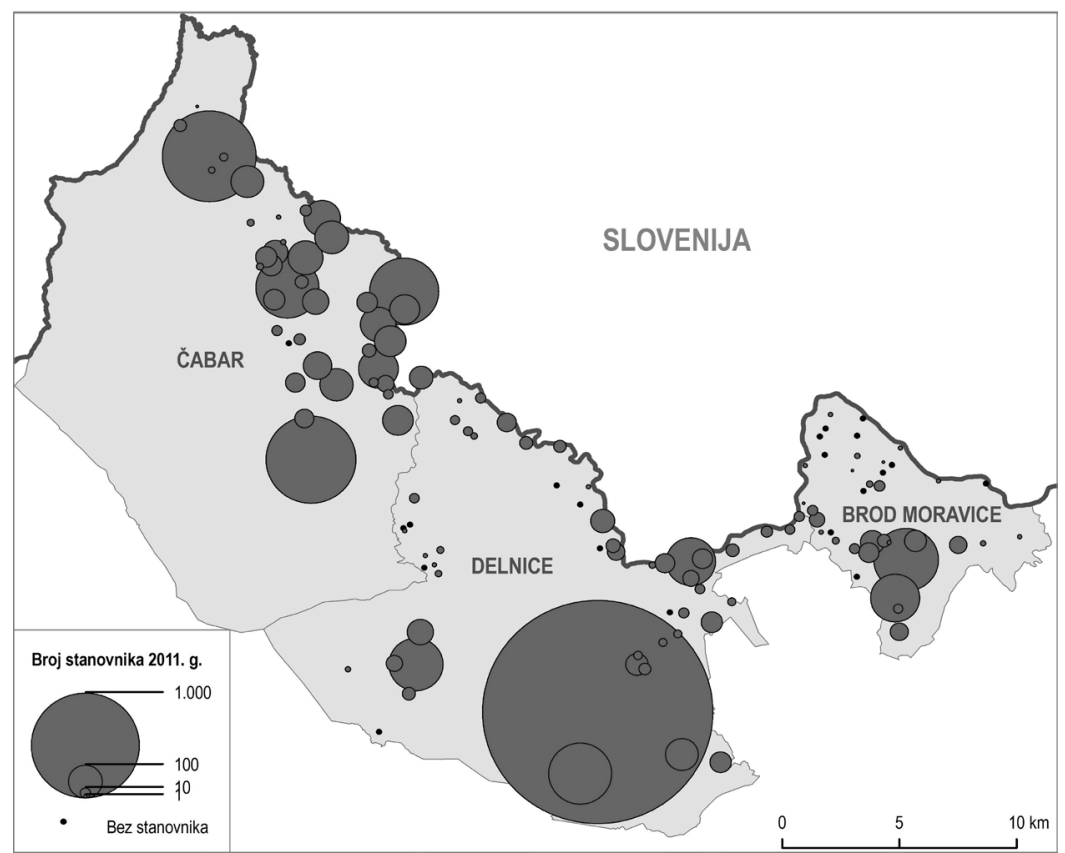

Izvor: Državni zavod za statistiku (2011.b). Popis stanovništva, kućanstava i stanova u Republici Hrvatskoj, 2011.: prvi rezultati. (Pregledano 03. kolovoza 2011. (http://www.dzs.hr/)

\subsection{Društveno-identitetska obilježja promatranoga prostora}

Unutar empirijskoga istraživanja na uzorku od 147 ispitanika (cca. 2,5\% ukupnoga broja stanovnika općina Brod Moravice, Delnice i Čabar) tri su se elementa nametnula kao relevantna obilježja u kontekstu istraživanja identiteta i društvene kohezije.

Prvi element odnosi se na posebnost identiteta pograničnoga područja provjerenoga pitanjem - Smatrate li da stanovnici ovoga kraja imaju poseban identitet u odnosu

9 Naime, kad emigracija uznapreduje, žene iz ruralnih područja iseljavaju češće i u većem broju nego muškarci koji su više vezani uz posjed (Nejašmić, 2005.). Odraz toga procesa je nemogućnost nalaženja bračnoga partnera, smanjenje stope rodnosti i produbljivanje depopulacije. Povezano s tim, u anketnom istraživanju sudjelovao je relativno visok broj muškaraca. 
na ostala naselja Gorskoga kotara? Rezultati su pokazali kako 42\% ispitanika smatra da imaju zaseban identitet u odnosu na ostala naselja Gorskoga kotara, 41\% ih smatra da stanovnici nemaju poseban identitet, dok ih 16\% nije sigurno. Međutim, pokazale su se značajnim unutarnje razlike među naseljima u stavovima ispitanika, ovisno o geografskom položaju naselja u odnosu na granicu i prometnu povezanost (izoliranosti) u odnosu na subregionalni centar (Delnice). Tako, primjerice, 67\% ispitanika u Prezidu i 64\% u Čabru smatra da stanovnici njihovih naselja imaju poseban identitet. Naime, radi se o naseljima smještenim na samoj hrvatsko-slovenskoj granici, a uz to, prema stavovima lokalnoga stanovništva, prometno su vrlo slabo povezana s Delnicama, te su djelomično upućena na rad u obližnje slovenske gradove. Od ukupnoga broja ispitanika u Brod Moravicama, 46\% ih smatra da stanovnici ovoga kraja imaju poseban identitet. Za razliku od Čabra i Prezida, Brod Moravice je prometno bolje povezan s Delnicama i udaljeniji od same granice, pa je i postotak niži. Brod na Kupi, udaljen samo nekoliko kilometara od središta rada (Delnica), iako je smješten na samoj granici, ima postotak od samo 28\%, kao i Delnice (29\%). Važno je istaknuti da su Delnice društveno-gospodarsko središte Gorskoga kotara. Iz navedenoga se može zaključiti da je pogranično područje ovih triju općina heterogeno područje u kojim su prometno-geografski položaj, kao i izoliranost, čimbenici poimanja sebe i zajednice. S rastom stupnja prometne povezanosti smanjuje se osjećaj posebnosti identiteta stanovnika, i obrnuto. Time je potvrđena (u teoretskom poglavlju) pretpostavljena zajednica mjesta u pograničnom području Gorskoga kotara.

Drugi element je percepcija vlastitih identiteta, pri čemu se od ispitanika tražilo da poredaju vlastite identitete po važnosti - od najvažnijega prema najmanje važnom (nadnacionalni, nacionalni, regionalni i lokalni). Prema provedenom istraživanju $32 \%$ ispitanika smatra regionalni identitet najvažnijim (što je razumljivo s obzirom na definiranost povijesno-geografske regije Gorskoga kotara), 31\% nacionalni, 29\% lokalni, a 5\% nadnacionalni. Na drugo mjesto 38\% ispitanika stavlja regionalni identitet, $27 \%$ nacionalni, 23\% lokalni, a 3\% nadnacionalni. Dakle, ispitanicima je najvažniji regionalni identitet (goranski), dok je lokalni identitet na trećem mjestu. Međutim, ako se razmatra geografska rasprostranjenost percepcije dominantnoga identiteta, jedino ispitanicima u Prezidu lokalni identitet je na prvom mjestu (38\%). Mogući razlog je prometna izoliranost od Delnica i bolja prometna dostupnost pojedinih naselja sa slovenskim gradovima (Stari Trg, Cerknica, Postojna), nego s Delnicama i ostalim gradovima u Hrvatskoj. U razgovoru s lokalnim stanovništvom utvrđeno je da značajan broj stanovnika Grada Čabra dnevno cirkulira na rad u obližnje slovenske gradove (Stari Trg, Cerknica). Osim toga, veći dio ispitanika naselja Prezid kao mjesto rođenja navodi Postojnu (Slovenija, rodilište) što ukazuje na činjenicu da je Prezid zbog bolje prometne dostupnosti u dijelu zdravstvene funkcije usmjeren na Postojnu, a ne na Delnice.

Ispitanici iz naselja Tršće (55\%), Brod Moravice (54\%) i Brod na Kupi (43\%) regionalni identitet stavljaju na prvo mjesto, što se može povezati s prometnom dostupnošću subregionalnoga središta Gorskoga kotara, iz čega se može izvesti zaključak da ispitanici regionalni identitet povezuju s administrativnim, gospodarskim i središtem 
rada kojem gravitiraju ${ }^{10}$. Što se pak lokalnoga identiteta tiče, premda nije na prvom mjestu hijerarhije identiteta ispitanicima promatranoga područja, on je zastupljen kao drugi najvažniji. Taj podatak moguće je povezati s prometnom povezanošću određenoga područja, posebice cestovnom povezanošću s centrima višega ranga. Dakle, lokalni identitet, iako naizgled ne ostavlja dojam važnoga, bitan je faktor koji je potrebno uzeti u obzir u analizi strukture i dinamike života zajednice sjeverozapadnoga dijela Gorskoga kotara. Taj lokalni identitet čije je postojanje osviješteno od strane lokalnoga stanovništva, u vezi je i s visokim stupnjem društvene kohezije pripadnika lokalne zajednice.

Treći element proizašao iz ovoga istraživanja odnosi se na karakter društvene kohezije. Na pitanje o procjeni stanja odnosa unutar zajednice (vezano uz oslanjanje na sumještane i prirodu odnosa), ispitanici su uglavnom zaokružili odgovor koji opisuje odnose kao dobre (82\% ih je odabralo odgovore gornjega dijela ljestvice; 1 - iznimno loše, 5 - iznimno dobro). Iz ovoga podatka neminovan je zaključak kako je društvena solidarnost i društvena kohezija u promatranim općinama na vrlo visokoj razini. Objašnjenje se nalazi u veličini promatranoga područja, ali i u specifičnostima Gorskoga kotara. Uglavnom je društvena kohezivnost viša u manjim zajednicama ${ }^{11}$ gdje postoji svakodnevan izravni kontakt između članova, što je i slučaj u promatranom području. U definiranju regije već je istaknuto kako je Gorski kotar izrazito depopulacijsko područje, što društvenu strukturu čini koherentnijom u vidu međuljudskih odnosa. Stanovništvo koje je ostalo na tom području prisiljeno je međusobno aktivno surađivati zbog nedostatka adekvatne cestovne infrastrukture i ekonomskih razloga. Uslužne djelatnosti (trgovina, školstvo, zdravstvo, administrativni poslovi i ostalo) nalaze se samo u naseljima višega ranga pa je zadovoljavanja funkcija potrebno putovati u susjedna naselja. Imajući na umu ostarjelost stanovništva, intergeneracijska suradnja između mještana je nužna. Socijalni kapital ovoga pograničnog područja visok je jer ljudi vjeruju jedni drugima s ciljem zajedničkoga preživljavanja u danoj okolini. Kulturna baština, također, u ovom kontekstu igra veliku ulogu. Ispitanici su kao jedan od bitnih čimbenika kreacije percepcije vlastite zajednice istaknuli narječja svojih mjesta koja ih razlikuju od ostatka regije. Navedena narječja su karakterističan sustav simbola i običaja koja služe za artikulaciju prenošenja kulture i načina života s obzirom da u svojoj jezičnoj riznici sadrže specifične izraze koji opisuju svakodnevnicu stanovnika različitih mjesta Gorskoga kotara. U kombinaciji s prometnom izoliranošću i blizinom Slovenije, narječje utječe na povećanje socijalnoga kapitala i društvene kohezije, što su pokazali rezultati anketa među stanovništvom pogranične zajednice Gorskoga kotara.

10 Ovaj zaključak je logičan iz razloga što u Delnicama, jedinom gradskom naselju promatranoga prostora, koje gravitiraju središtima višega ranga (Rijeka, Karlovac), nacionalni identitet primaran (35\% ispitanika).

11 Autori se pozivaju na istraživanja o tzv. Dunbarovom broju koja tvrde da su odnosi u manjim zajednicama harmoničniji od onih u većima - veće zajednice zahtijevaju restriktivnija pravila kako bi se održala društvena kohezija (Dunbar, 1992.). 
S tim u vezi, istraživanje je pokazalo kako postoji i određena korelacija u razmišljanjima stanovništva o kvaliteti odnosa unutar pogranične zajednice i odnosa na državnoj razini $(\mathrm{r}=0,5)^{12}$. Konkretnije, rastom percepcija pozitivnih odnosa u lokalnoj pograničnoj zajednici (društvena solidarnost), raste i pozitivna percepcija međudržavnih odnosa. U uvodu je istaknuto kako je postojanje društvene solidarnosti jedan od uvjeta postojanja lokalnih zajednica, te ovaj podatak i na empirijskoj razini potvrđuje teoretsku pretpostavku. Osim toga, kako međudržavni odnosi Hrvatske i Slovenije u hrvatskom društvu nisu pozitivno percipirani, te se može govoriti i o negativnom zaokretu u geopolitičkoj percepciji (Zorko, 2011.), ovaj podatak ukazuje na još jednu posebnost u stavovima pogranične zajednice i njihovu različitost s obzirom na ukupno stanovništvo i trendove na državnoj razini. Navedeni zaključak dobiva još i više na vrijednosti zna li se kako je nacionalna percepcija hrvatsko-slovenskih odnosa uglavnom negativna.

\section{Zaključak}

U radu je pretpostavljeno da u pograničnom području sjeverozapadnoga Gorskog kotara postoji društvena kohezija koja omogućava definiranje toga prostora pograničnom zajednicom. Rezultatima empirijskoga istraživanja usmjerenim na pitanje identitetske politike i društvenu solidarnost, dokazana je glavna hipoteza. U anketnom upitniku više od 2/5 ispitanika osjeća pripadnost lokalnom identitetu, a trećina ističe lokalni identitet kao prvi osobni identitet koji ih karakterizira. Ovi podaci potvrđuju postojanje pogranične zajednice na sjeverozapadnom dijelu Gorskoga kotara, definirane prema kriteriju identiteta. Osim navedenoga, istražena je i percepcija kvalitete tih odnosa na lokalnoj i državnoj razini. Kvaliteta odnosa i stavovi ispitanika koji se ne uklapaju u sveukupne trendove na državnim razinama (Klemenčić, 2001.) dodatno ukazuju na posebnost pogranične zajednice te potvrđuje pretpostavke o karakterističnoj formi identiteta. Važno je napomenuti kako, premda je potvrđeno postojanje pogranične zajednice na temelju identiteta, ona nije prostorno homogena, odnosno dokazani identitet jača (ili slabi) ovisno o stupnju prometne povezanosti sa subregionalnim središtem (Delnicama) i blizini granične linije. Članak je dodatno rasvijetlio strukturu društvene kohezije povezujući prometni i geografski položaj s društvenim čimbenicima čija sinergija povoljno djeluje na socijalnu koheziju, pokazujući kako je ona visoka te pozitivno korelirana s percepcijom hrvatsko-slovenskih odnosa.

Ovim istraživanjem pokazalo se kako su pogranične zajednice nedovoljno istražene u Republici Hrvatskoj, a kako posjeduju društvenu dinamiku i istraživački potencijal. Stoga, preporuke za daljnja istraživanja su se same nametnule. Prva od njih je metodološkoga karaktera. Naime, u budućim istraživanjima trebalo bi povećati

\section{Pitanje: Kako biste ocijenili odnose na državnoj razini između Hrvatske i Slovenije?}

(1 - odnosi su iznimno loši; 2 - odnosi su loši; 3 - odnosi nisu niti dobri, niti loši, ne znam, svejedno mi je; 4 - odnosi su dobi; 5 - odnosi su iznimno dobri). 
uzorak ispitivanja kako bi se povećao eksplikacijski potencijal. Svjesni da je upravo navedeno jedna od limitacija ovoga rada, usprkos tomu, moguće je zaključiti određene indikacije relevantne za područje kulturne i političke geografije. Također, druga sugestija ide u smjeru daljnjih politoloških istraživanja odnosa između dviju država, koje obuhvaća konkretna pogranična zajednica. Zanimljivo bi bilo napraviti komparativnu analizu društvene kohezije, u ovom slučaju, hrvatskoga i slovenskoga dijela pogranične zajednice, te ih usporediti s aktualnom državnom politikom. Uz to, preporučujemo i koncentraciju na javne politike, također u komparativnoj perspektivi. Naime, iz politološke perspektive važno je znati postoje li usmjerene i strukturirane odluke na lokalnoj razini koje bi potaknule društveno-ekonomski razvoj pogranične zajednice. Osim problema obuhvaćenih ovim radom istaknuli su se i mnogo kompleksniji problemi poput brojčane nejednakosti po spolu, ostarjelosti dobnoga sastava stanovništva i nedostatka radnih mjesta koji zaslužuju biti detaljnije istraženi. Zaključno, ovim istraživanjem utvrđene su pretpostavke o nastavku negativnih demogeografskih procesa iz prethodnoga razdoblja koji neminovno vode do daljnjega smanjenja broja stanovnika. Time se otvorilo pitanje u kakvom su odnosu demogeografski procesi i promjene identiteta u Hrvatskoj, na koje bi odgovor bilo moguće dobiti komparativnom analizom identiteta u područjima s različitim smjerom i intenzitetom demografskih kretanja.

\section{Literatura}

1. Bufon, M. (2001). Osnove politične geografije II. Ljubljana: Univerza v Ljubljani, Filozofska fakulteta, Oddelek za geografijo.

2. Cerutti, F. (2006). Identitet i politika. Zagreb: Politička kultura.

3. Cvrtila, V.; Zorko, M. i Banovac, M. (2010). Koncept pograničnih zajednica i manjinski odnosi. Mecunarodne studije, 10 (3-4): 18-39.

4. Day, G. (2006). Community and Everyday Life. London \& New York: Routledge.

5. Dunbar, R.I.M. (1992). Neocortex size as a constraint on group size in primates. Journal of Human Evolution, 22: 469-493.

6. Durkheim, E. (1984). The Division of Labor in Society. New York: The Free Press.

7. Geiger Zeman, M. i Zeman, Z. (2010). Uvod u sociologiju (održivih) zajednica. Zagreb: Institut društvenih znanosti Ivo Pilar.

8. Gerring, J. (2007). Case Study Research. Principles and Practices. Cambidge, New York: Cambridge University Press.

9. Hartshorne, R. (1936). Suggestions on the Terminology of Political Boundaries. Annals of the Association of American Geographers, 26: 56-57.

10. Klemenčić, M. (2001). Političkogeografski aspekti hrvatsko-slovenskih odnosa u razdoblju 1991. - 2000. Dela, 16: 17-28.

11. Klemenčić, M. (2005). Igre granicama. Svijest o političkim granicama u političkoj geografiji, u: Toskić, A. (Ur.). Zbornik radova Trećeg brvatskog geografskog kongresa. Zagreb: Hrvatsko geografsko društvo.

12. Kurczewska, J. (Ed.) (2006). Polish Borders and Borderlands in the Making. From the Field Studies of Polish Sociologists and Anthropologists. Warsaw: Ifis Publishers. 
13. Nejašmić, I. (1992). Depopulacija u Hrvatskoj. Korijeni, stanje, izgledi. Zagreb: Globus nakladni zavod i Institut za migracije i narodnosti

14. Nejašmić, I. (2008). Stanouništvo Hrvatske: demogeografske studije $i$ analize. Zagreb: Hrvatsko geografsko društvo.

15. Newman, D. and Kliot, N. (Eds.) (2000). Geopolitics at the End of the Twentieth Century. The Changing World Political Map. London/Portland: Frank Cass.

16. Newman, D. and Paasi, A. (1998). Fences and Neighbours in the Postmodern World: Boundary Narratives in Political Geography. Progress in Human Geography, 22 (2): 186-207.

17. Njegač, D. i Pejnović, D. (2002). Gorska Hrvatska, u: Borovac, I. (Ur.). Veliki atlas Republike Hrvatske. Zagreb: Mozaik knjiga.

18. Ó Tuathail, G. (1998). Political geography III: Dealing with Deterritorialization. Progress in Human Geography, 22 (1): 81-93.

19. Parekh, B. (2008). Nova politika identiteta. Zagreb: Politička kultura.

20. Rumley, D. and Minghi, V. J. (1991). The Geography of Border Landscapes. London: Routledge.

21. Tönnies, F. (2002). Community and Society. New York: Dover Publications.

22. Yin, R. K. (2007). Studija slučaja - dizajn i metode. Zagreb: Fakultet političkih znanosti Sveučilišta u Zagrebu.

23. Zorko, M. (2011). Konfliktni potencijal dobrosusjedskih odnosa: slučaj Hrvatske i Slovenije. Političke perspektive, 2: 43-62.

\section{Izvori}

Carinska uprava Republike Hrvatske [CURH] (2011). Granični prijelazi i područja nadležnosti carinarnica. Pregledano 18. kolovoza 2011. (http://www.carina.hr/ CURH/Dokumenti/Globalni/Karta_Carinarnica_RH.pdf).

Državni zavod za statistiku (2005). Naselja i stanovništvo Republike Hrvatske 1857. - 2001. (CD-ROM). Zagreb: Državni zavod za statistiku.

Državni zavod za statistiku (2010). Tablogrami: rođeni i umrli po naseljima Republike Hrvatske 2001. - 2009. Zagreb: Državni zavod za statistiku.

Državni zavod za statistiku (2011a). Model diferencijacije urbanih, ruralnih i prijelaznih naselja u Republici Hrvatskoj. Zagreb: Državni zavod za statistiku.

Državni zavod za statistiku (2011b). Popis stanovništva, kućanstava i stanova u Republici Hrvatskoj 2011. prvi rezultati. Pregledano 03. kolovoza 2011. (http://www. dzs.hr/).

Zakon o lokalnoj i područnoj (regionalnoj) samoupravi, Narodne novine 33 od 2001.

Državni zavod za statistiku (2003): Popis stanovništva, kućanstava i stanova 31. ožujka 2001. stanovništvo prema spolu i starosti, po naseljima (CD-ROM). Zagreb: Državni zavod za statistiku. 
Marta Zorko

Faculty of Political Science, University of Zagreb, Croatia

e-mail:mzorko@fpzg.hr

Ivan šulc

Faculty of Science, Department of Geography, University of Zagreb, Croatia

e-mail: isulc@geog.pmf.hr

Marko Kovačić

Faculty of Political Science, University of Zagreb, Croatia

e-mail: mkovacic@fpzg.hr

\title{
Cross-border Communities in the Republic of Croatia: Local Identity in Gorski kotar, the Croatian-Slovenian Cross-border Region
}

\begin{abstract}
Because of the fact that there has been a change in the understanding of the term "border" in the contemporary world, more and more consideration has been given to the research of subjects in cross-border areas. Researchers have started to focus more on the relations between subjects in those cross-border regions and micro regional centers in order to understand the structure and the dynamics of those areas. In addition, the term "border" has changed in its geopolitical sense within the triangle of entities: power-area-inhabitants. That is the reason why only multidisciplinary research is adequate enough for the study of cross-border regions. This paper analyzes the social cohesion and identities in the northwestern part of Gorski kotar (Croatia) in the Croatian-Slovenian cross-border region. Using the combination of quantitative and qualitative research methods, the authors argue that there is a high level of social cohesion in that area and a specific identity of local inhabitants. The nature and structure of both are analyzed in this paper. The authors analyze how a specific location influences interpersonal relations and the perception of self in that environment.
\end{abstract}

Key words: identity, social cohesion, Gorski kotar, cross-border communities, co-operation in cross-border regions, the Republic of Croatia. 